\title{
MODELLING FLOW AND INORGANIC NITROGEN DYNAMICS ON THE HAMPSHIRE AVON: LINKING UPSTREAM PROCESSES TO DOWNSTREAM WATER QUALITY
}

\section{Li Jin'1, Paul G. Whitehead ${ }^{2}$, Catherine Heppell ${ }^{3}$, Katrina Lansdown ${ }^{3,5}$, Duncan Purdie ${ }^{4}$ and Mark Trimmer ${ }^{5}$}

${ }^{1}$ Geology Department, State University of New York College at Cortland, Cortland NY 13045, USA

${ }^{2}$ School of Geography and the Environment, University of Oxford, South Parks Road, Oxford OX1 3QY, UK

${ }^{3}$ The School of Geography, Queen Mary University of London, Mile End Road, London E1 4NS, UK

${ }^{4}$ Ocean \& Earth Science, University of Southampton, National Oceanography Centre, Southampton, European Way, Southampton, SO14 3ZH, UK

${ }^{5}$ School of Biological and Chemical Sciences, Queen Mary University of London, Mile End Road, London E1 4NS, UK

Corresponding author: Professor Li Jin at li.jin@cortland.edu

\begin{abstract}
Managing diffuse pollution in catchments is a major issue for environmental managers planning to meet water quality standards and comply with the EU Water Framework Directive. A major source of diffuse pollution is from nitrogen, with high nitrate concentrations affecting water supplies and in-stream ecology. A dynamic, process based model of flow, nitrate and ammonium (INCA-N) has been applied to the Hampshire Avon as part of the NERC Macronutrient Cycles Programme to link upstream and downstream measurements of water chemistry. The model has been calibrated and validated against Environment Agency discharge and solute chemistry data, as well as a data set collected from a river site immediately upstream of the estuary tidal limit. Upstream measurements of denitrification at six sites have been used to evaluate nitrate removal rates in vegetated and non-vegetated conditions. Results show that sediments underlying vegetation were associated with significantly higher rates of nitrate removal than un-vegetated sediments (with an average increase of 245\%). These data have been used to scale up rates of nitrate loss to the whole catchment scale and have been implemented via the model. The effects of streambed geology and macrophyte cover on catchment-scale nitrogen dynamics are explored and nutrient fluxes entering the estuary are evaluated. The model is used to test a strategy for nitrogen reduction assessed using a nitrate vulnerable zone (NVZ) methodology. It suggests that nitrate and ammonium concentrations could be reduced by $10 \%$ in 10 years and much lower nitrogen level can be achieved but only over a long time period.
\end{abstract}

Key words: Nitrate, Ammonium, Pollution, Denitrification, Rivers, Estuaries 


\section{INTRODUCTION}

The role of dissolved inorganic nitrogen (DIN) in UK lowland rivers has been of rising concern over the years as river water and groundwater concentrations approach the World Health and EU Drinking Water limits for nitrate of $11.3 \mathrm{mg}$ N/L (Neal et al., 2006, 2012) and also high concentrations of DIN have been related to reduced biodiversity in rivers and lakes (Carmargo and Alonso, 2006; Grizzetti et al., 2011; Sala et al., 2000). In the UK upland rivers and catchments, DIN is also a concern because of the impacts of nitrate and ammonium deposition on terrestrial biodiversity and also the role of DIN as a strong acid anion leading to acidification of upland waters (Fowler et al., 1998 and 2004; Tipping et al., 2008). Trends in atmospheric nitrogen $(\mathrm{N})$ have remained fairly stable and reduced industrial emission has been offset by increased vehicle emissions (Galloway et al., 2014). There has also been a drive to reduce $\mathrm{N}$ fertilizer additions by creating nitrate vulnerable zones (NVZ) and restricting $\mathrm{N}$ application rates onto arable crops and improved grassland. In groundwater-fed rivers of the UK there is, as yet, little evidence to suggest that nitrate concentrations have reduced significantly in response to restricted fertilizer application (Burt et al, 2011; Howden et al, 2010). In Denmark, however, N addition rates have been significantly reduced and there are long term reductions in DIN in groundwaters and rivers (Hansen et al., 2011; Kronvang et al., 2008). At the same time, the dynamics of macronutrients in the environment are changing due to enhanced temperatures, altered reaction kinetics of microbiallymediated processes, as well as changing precipitation, atmospheric and hydrological patterns. The interacting processes and transport mechanisms inevitably mean that nutrient science is complex. To make any significant progress, an interdisciplinary approach to the problem is needed and to this end Natural Environment Research Council (NERC) has funded the Macronutrient Cycles Programme (Whitehead and Crossman, 2012).

The Macronutrient Cycles Programme (MNC) was set up to evaluate the cycles of N, phosphorus (P) and carbon (C) as these are fundamental to controlling food supply, potable water quality, pathogens, air quality and climate. In addition, they also control ecosystems on the land surface and in rivers, lakes, wetlands, estuaries, coasts and oceans. The overarching goal of the MNC programme has been to quantify the scales (magnitude and spatial/temporal variation) of $\mathrm{N}$ and $\mathrm{P}$ fluxes and the nature of transformations through the catchment under a changing climate and perturbed carbon cycle, with specific aims as follows:

1. to evaluate the nature and scale of macronutrient $(\mathrm{N}, \mathrm{C})$ exchange between the airshed and terrestrial system and consequences for fluxes (N, P, C) to soil, freshwater and atmosphere systems (atmosphere-terrestrial-freshwater feedback system);

2. to determine the role and spatial and temporal variation of macronutrients $(\mathrm{N}, \mathrm{P}, \mathrm{C})$ on key limiting processes and ecosystem functions (i.e. decomposition, productivity, carbon sequestration) and consequent export at the catchment scale (terrestrial-freshwater systems);

3. to advance understanding of the co-limitation of N/P for eutrophication control in terrestrial systems and along the entire freshwater system to the estuarine boundary (freshwater system);

4. to determine the implications of nutrient enrichment on the fate and effects of other non-nutrient contaminants, such as pathogens and ozone, including impacts on human health and biodiversity. 
As part of this programme, an extensive set of local and catchment scale experiments have been established to monitor and measure $\mathrm{N}, \mathrm{P}$ and $\mathrm{C}$ transfers from the terrestrial environment, through soils and groundwaters to the streams in the Hampshire Avon (See Trimmer et al. project description at: http://macronutrient-cycles.ouce.ox.ac.uk/projects/lateral-exchange.html). Another set of key objectives from the programme has been the development of integrated models that can describe the complex process interactions occurring across a range of scales from reach to catchment. Such models can then be used to test process-based hypotheses related to the transfer of nutrients from catchment to coast, and to provide information on nutrient loads to downstream estuaries and coastal systems. Figure 1 shows the range of modelling approaches within the MNC programme and how the models link to the different components of the science in terrestrial systems, soils, rivers and estuaries.

In this paper, we use a catchment-based modeling approach to assess hydrology and $\mathrm{N}$ dynamics of the Hampshire Avon and consider the scale up of process-based measurements of denitrification rates in the upper reaches (Lansdown et al., in prep) to the entire catchment. The model has been used to generate fluxes of DIN moving through the lower reaches of the river to enter the downstream estuary system of Christchurch Harbor. As much of the groundwater-fed Hampshire Avon is dominated by aquatic Ranunuculus spp. (a primary reason for the Designation of Special Area of Conservation) and because the sediments beneath such macrophytes have previously been shown to be biogeochemical hotspots (Trimmer et al., 2009), we also investigate the scale of nitrate loss that may be associated with denitrification in reactive vegetated sediments and the likely impacts of such vegetated sediments on fluxes of DIN leaving the catchment. A strategy for nitrogen reduction using a Nitrate Vulnerable Zone (NVZ) has been assessed using the model.

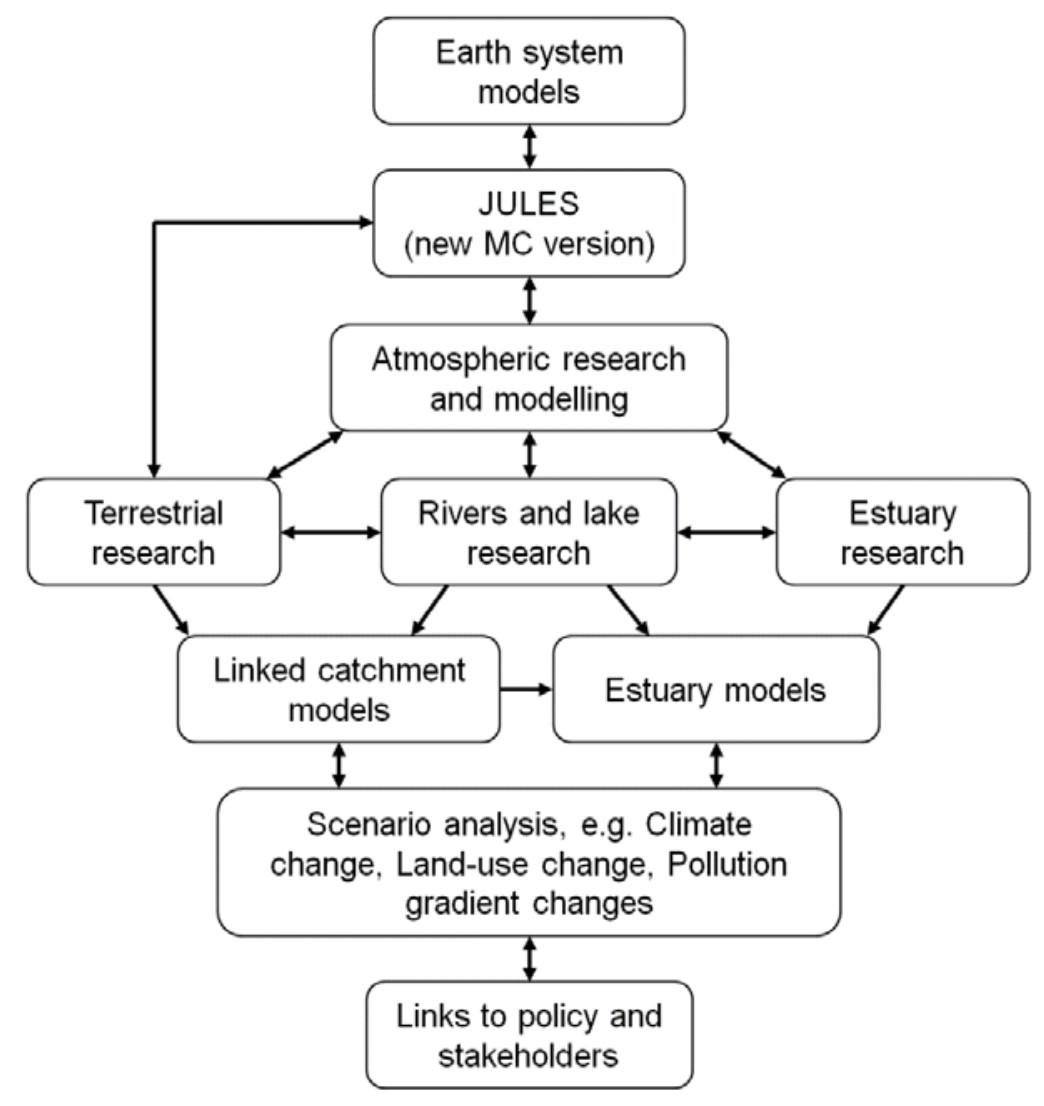


Figure 1 The Modelling/Science/Stakeholder Strategy for the Macronutrient Cycles Programme. JULES (the Joint UK Land Environment Simulator) is a land surface model.

\section{HAMPSHIRE AVON CATCHMENT}

The Hampshire Avon is located in Southern England with a catchment area of approximately 1,700 km². Its sources are in the Vale of Pewsey, Wiltshire, and the catchment outflow is to the Solent through its estuary at Christchurch Harbour in Dorset. A number of tributaries join the Avon upstream of Salisbury including the Bourne and Upper Avon (Upavon East and Upavon West) from the North, the Wylye from Northwest and the Nadder from West (Figure 2). The Ebble and several small tributaries join the main Avon south of Salisbury. The upper reaches of the large tributaries (Upavon East, Upavon West, Wylye, and Nadder) are fed by large springs from the Upper Greensand aquifer (Figure 3). The Greensand formation dips south and underlies the Chalk of Salisbury Plain which dominates the upper catchment of the Avon, as shown in Figure 3, whereas in the southern reaches of the river the Chalk formation becomes confined beneath London Clay.

Baseflow indices at Environment Agency (EA) flow gauging stations are 0.7 at Upavon West, 0.89 at Upavon East, 0.81 at Nadder (Wilton), 0.86 at main Avon (Knapp Mill), 0.89 at Wylye (South Newton) and 0.91 at Bourne (Laverstock) (http://www.ceh.ac.uk/data/nrfa/). Thus the baseflow or groundwater contribution to the Avon and many of its tributaries is generally high (> 70\%) and remains so throughout the year. The River Sem, in the West of the catchment, is an exception with a groundwater contribution of 20-55\% depending on location. This tributary of the River Nadder flows across a mix of Greensand, Gault and Kimmeridge Clay (Allen et al., 2014) and this geology gives rise to a flashier hydrological response than other tributaries in the upper Hampshire Avon catchment. South of Salisbury, the river flow is largely from surface runoff and the groundwater contribution becomes less significant. Groundwater recharge to the rivers typically follows two pathways, matrix flow and fracture flow. Matrix flow is the dominant flow path and accounts for approximately $80 \%$ of the total recharge (Bryan et al., 2015). The residence time of matrix flow is on the order of tens of years (Bryan et al., 2015). Fracture flow occurs when the ground becomes saturated and recharge flows through the rock fractures. This type of flow usually reaches the water table within days or weeks.

Average rainfall in the Avon catchment is between 700 to $800 \mathrm{~mm} /$ year near the coast and increases to greater than $900 \mathrm{~mm} /$ year over the Nadder and Wylye. There are 12 flow gauging stations and over 30 water quality monitoring stations managed by Environment Agency (EA, England, UK), which makes it an excellent place for flow and water quality studies. However, the frequency and duration of the water quality sampling vary greatly among stations. Flow has been typically recorded every day. Water quality measurements for nitrate and ammonium have been obtained on a varying time scale from weekly to monthly.

The Avon catchment is dominated by agricultural land (approximately 75\%) and urban areas (approximately 15\%) with a very small percentage of forest and wetlands. Agricultural activities are diverse in the catchment with cereal and improved grasslands for both dairy and sheep farming. Elevated phosphorus, nitrate and sediment levels derived from agricultural land are believed to have contributed to nutrient enrichment (Jarvie et al., 2013; Whitehead et al., 2014). There can be extensive seasonal 
growth of macrophytes in many tributaries which can affect the chemical balances, such as $\mathrm{P}$ controls (Whitehead et al, 2014), as well as dissolved oxygen concentrations and the $\mathrm{N}$ balance (Cox, 2003).

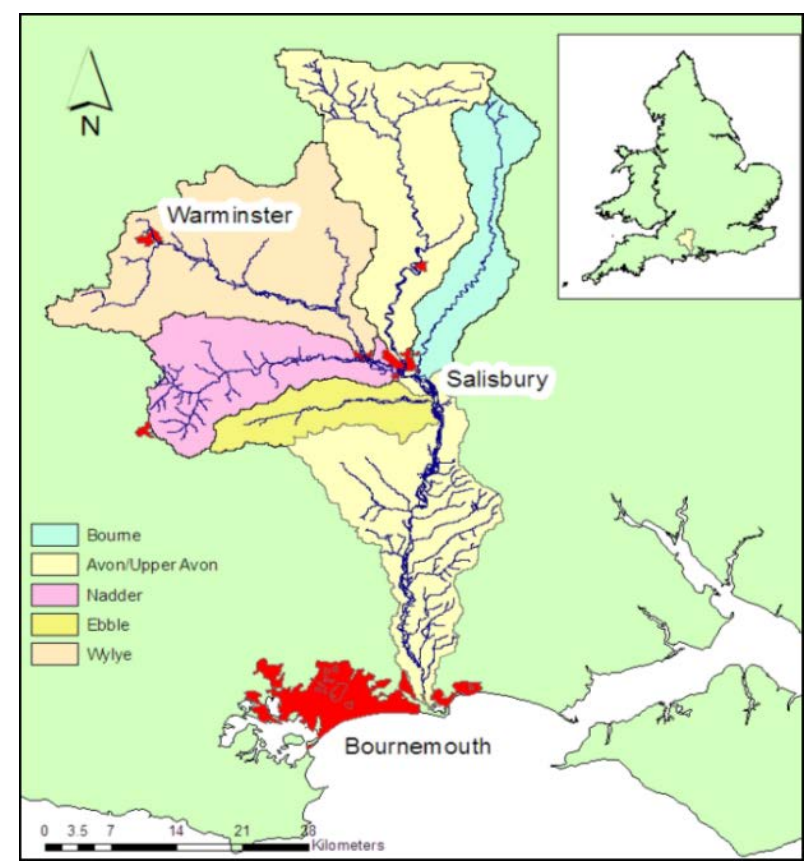

Figure 2 The Hampshire Avon catchment in Southern England with 5 main sub-catchment areas draining into the lower reaches of the river, before discharging into Christchurch Harbour in the Bournemouth Region of the coastline. The red areas on the map are major cities and towns.

\section{THE MULTI-BRANCHED INCA-N MODEL}

The Integrated Catchment model for Nitrogen (INCA-N) was first developed by Whitehead et al. in 1998 to simulate flow, nitrate and ammonium concentrations in soil, streams and groundwater (Whitehead et al., 1998 a, b) and later modified by Wade et al. (2002). The process-based INCA model tracks the movement, stores and fluxes of water, nitrate and ammonium in both the land and in-stream components of a river system. The semi-distributed nature of the model divides the water course into reaches with associated sub-catchments, which are further grouped into different land uses. All landbased processes are then calculated for a generic $1 \mathrm{~km}^{2}$ cell for each land use class within each subcatchment. Water, nitrate and ammonium outputs from the $1 \mathrm{~km}^{2}$ cell for each land use class are then multiplied by its area, which provides inputs of that particular land use class. All land use inputs are summed to transport fluxes and loads to the sub-catchment of the reach. Point sources such as sewage treatment works (STWs) can be fed directly into any reach either in the main river or any tributaries. The model then sequentially integrates $\mathrm{N}$ inputs to multiple reaches. The traditional INCA-N set up has the water course as a single main stem. The recent development of multi-branched structure (Whitehead et al., 2011) allows the model to simulate tributaries using a branched setup, which can represent complicated river networks like the River Avon. Now multi-branched INCA-N may have any number of streams and tributaries with no restrictions on stream order. 


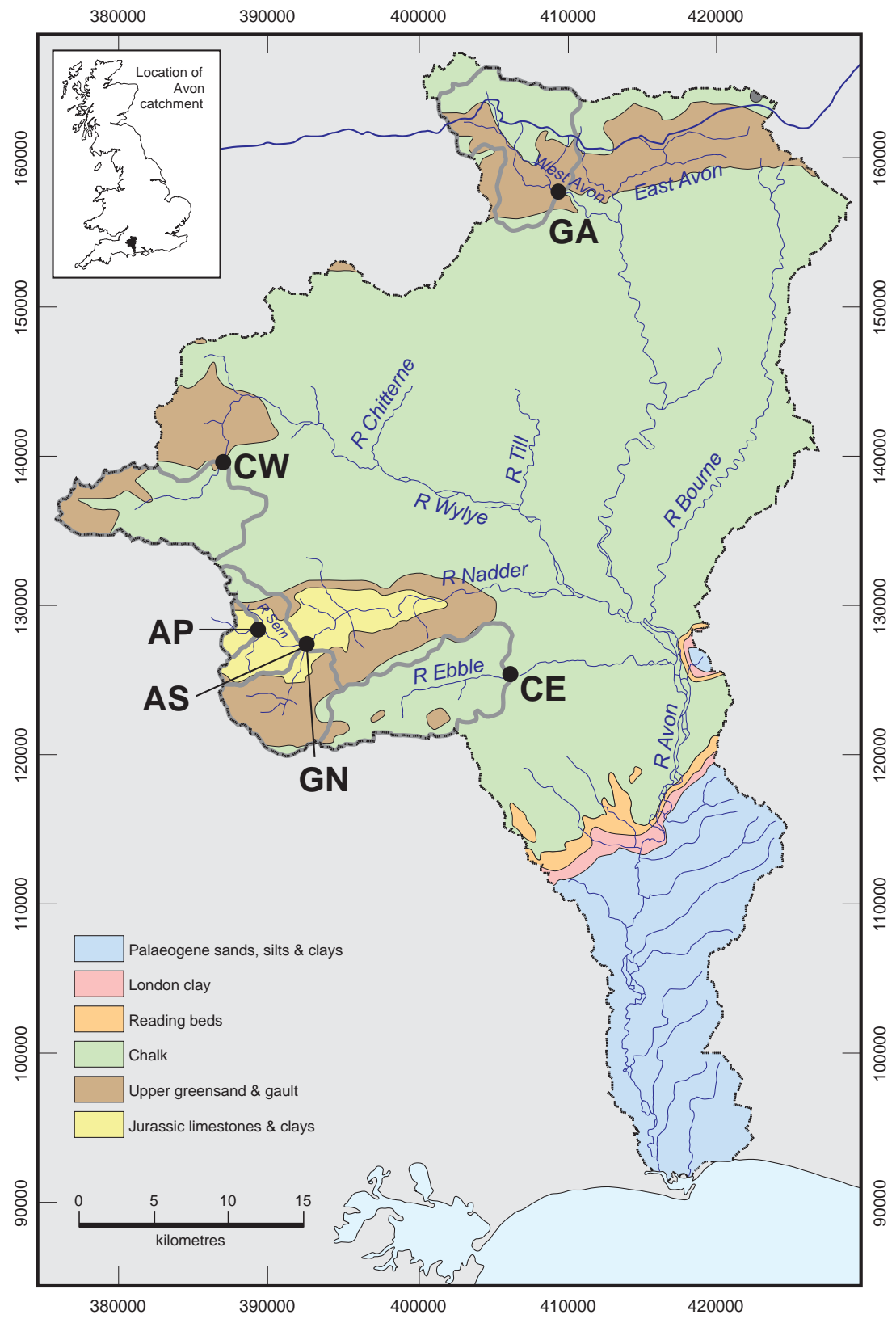

Figure 3 Geology map of the Hampshire Avon catchment, showing six experiment sites (GA, CW, AP, AS, GN and CE) in the upper sub-catchments.

\section{INCA-N APPLICATION TO THE HAMPHSHIRE AVON}

In order to model the River Avon, the whole catchment has been divided into 43 reaches and associated sub-catchments (Table 1 and Figure 4). Reach boundaries were selected at flow gauging stations, water quality monitoring stations and confluences. Each main tributary is simulated individually by splitting into multiple reaches to reflect the heterogeneity of the catchment with different geology and land uses. The sub-catchment delineation was derived using a Digital Terrain Model (DTM) in ArcGIS. Land use classes used in INCA-N include urban, intensive agriculture (arable land or permanent crops), non- 
intensive agriculture (natural grassland), wetlands and forest (Table 1). All the STWs in the Hampshire Avon have been incorporated into the model as indicated in Table 2. The INCA-N model requires inputs of daily time series of hydrological effective rainfall (HER), soil moisture deficit (SMD), rainfall and air temperature. HER is the rainfall that contributes to runoff and both HER and SMD were generated by the Meteorological Office Rainfall and Evapotranspiration System (MORECS, Thompson et al., 1981). Table 3 lists key data which are required to parameterize the INCA-N model.

INCA-N model was first set up and calibrated between 2000 and 2009. Data from 2010 to 2014 were used for model validation. For model calibration and validation, INCA-N requires streamflow and water quality data such as concentrations of nitrate and ammonium (Table 3). When comparing model outputs against observed parameters using the EA monitoring data, we first ensure that a reasonable representation of the hydrology (streamflow component) is obtained. The water quality aspect is more challenging due to the uncertainties from input (different diffuse sources and point sources), analytical difficulties and errors of the observed concentrations and point sample representativeness. Therefore, direct comparison of daily nitrate and ammonium concentrations between simulated and observed values are used for visual assessment. Statistical analysis was performed on the monthly average loads on reaches where both flow and water quality data are available. A sensitivity analysis in this study was performed to assess the effects of variability of in-stream process rates e.g. nitrate removal on model simulations.

The calibrated model was then used to assess the predictive capabilities for estimating the downstream riverine inputs to the Christchurch Harbour estuary (http://macronutrientcycles.ouce.ox.ac.uk/projects/quantifying.html) (Purdie et al., 2015). Weekly water samples were collected from Knapp Mill between $25^{\text {th }}$ April 2013 and $19^{\text {th }}$ December 2014 for nutrient analysis. On returning to the lab, water samples were filtered through a glass fibre filter then fixed immediately with $0.015 \mathrm{M}$ mercuric chloride $(750 \mu \mathrm{L}$ in $150 \mathrm{~mL}$ ) prior to later analysis. In addition, high frequency samples for nutrient analysis were collected every 8 to 15 hours with an ISCO automated water sampler (RS Hydro, UK) between $22^{\text {nd }}$ November 2013 and $19^{\text {th }}$ December 2014. Concentrations of inorganic nutrients were determined at the University of Portsmouth using a QuAAtro segmented flow nutrient analyser (SEAL Analytical, UK). 


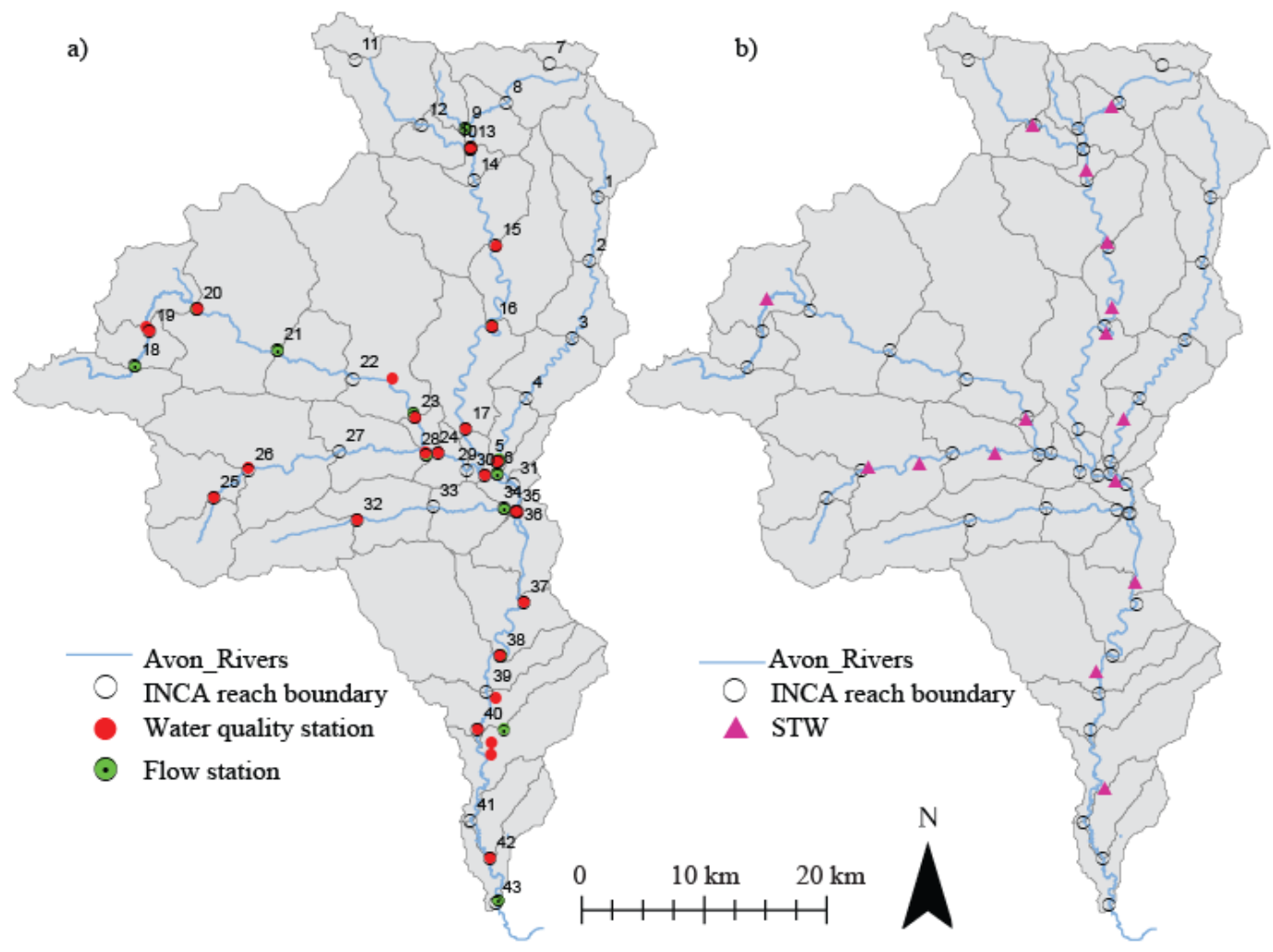

Figure 4 Multi-branch INCA-N setup showing reach boundaries, locations of EA flow gauging stations, water quality monitring sites and STWs.

Table 1 INCA reach and sub-catchment characteristics with land use percentages.

\begin{tabular}{|l|l|l|l|l|l|l|l|l|l|}
\hline Reach & INCA ID & \multicolumn{1}{|c|}{ River } & $\begin{array}{c}\text { Area } \\
\mathbf{( k m}^{\mathbf{2}}\end{array}$ & $\begin{array}{c}\text { Reach } \\
\text { Length } \\
\mathbf{( m )}\end{array}$ & $\begin{array}{c}\text { Urban } \\
\mathbf{\%}\end{array}$ & $\begin{array}{c}\text { Intensive } \\
\text { Agriculture } \\
\mathbf{\%}\end{array}$ & $\begin{array}{c}\text { Grassland } \\
\mathbf{\%}\end{array}$ & $\begin{array}{c}\text { Wetlands } \\
\mathbf{\%}\end{array}$ & $\begin{array}{c}\text { Forest } \\
\mathbf{\%}\end{array}$ \\
\hline 1 & Bourne01 & Bourne & 51.2 & 28535 & 14.3 & 54.1 & 22.6 & 0.2 & 8.8 \\
\hline 2 & Bourne02 & Bourne & 26.2 & 26144 & 12.0 & 42.3 & 34.7 & 0.2 & 10.9 \\
\hline 3 & Bourne03 & Bourne & 33.9 & 26144 & 11.4 & 51.2 & 29.9 & 0.2 & 7.3 \\
\hline 4 & Bourne04 & Bourne & 37.9 & 33984 & 14.1 & 51.8 & 29.8 & 0.2 & 4.1 \\
\hline 5 & Bourne05 & Bourne & 16.2 & 11238 & 27.4 & 43.1 & 26.5 & 0.4 & 2.5 \\
\hline 6 & Bourne06 & Bourne & 0.9 & 3357 & 44.4 & 21.7 & 22.4 & 1.0 & 10.5 \\
\hline 7 & Avon07 & Main Avon & 9.6 & 3772 & 11.1 & 45.0 & 32.1 & 0.3 & 11.5 \\
\hline 8 & Avon08 & Main Avon & 41.1 & 9937 & 15.4 & 46.7 & 31.9 & 0.5 & 5.4 \\
\hline 9 & Avon09 & Main Avon & 12.1 & 7038 & 11.6 & 43.8 & 36.6 & 0.8 & 7.2 \\
\hline 10 & Avon10 & Main Avon & 23.1 & 16528 & 14.4 & 47.9 & 29.6 & 0.9 & 7.2 \\
\hline 11 & Avon11 & West Avon & 12.9 & 1962 & 16.1 & 54.5 & 27.0 & 0.2 & 2.2 \\
\hline 12 & Avon12 & West Avon & 53.5 & 15357 & 16.9 & 46.1 & 33.0 & 0.5 & 3.4 \\
\hline 13 & Avon13 & West Avon & 18.2 & 7089 & 14.0 & 57.3 & 24.4 & 0.6 & 3.8 \\
\hline 14 & Avon14 & Main Avon & 8.2 & 4099 & 12.7 & 58.9 & 24.8 & 0.9 & 2.7 \\
\hline 15 & Avon15 & Main Avon & 78.0 & 11696 & 6.5 & 51.1 & 40.1 & 0.3 & 2.0 \\
\hline 16 & Avon16 & Main Avon & 69.8 & 13706 & 12.0 & 39.0 & 40.6 & 0.5 & 7.9 \\
\hline 17 & Avon17 & Main Avon & 68.9 & 16978 & 14.6 & 48.5 & 32.6 & 0.6 & 3.6 \\
\hline
\end{tabular}




\begin{tabular}{|l|l|l|l|l|l|l|l|l|l|}
\hline 18 & Wylye18 & Wylye & 50.1 & 24238 & 6.8 & 50.4 & 35.5 & 0.2 & 7.2 \\
\hline 19 & Wylye19 & Wylye & 21.9 & 17484 & 10.0 & 38.8 & 40.0 & 0.2 & 10.8 \\
\hline 20 & Wylye20 & Wylye & 41.9 & 24258 & 16.6 & 24.0 & 37.7 & 0.6 & 21.1 \\
\hline 21 & Wylye21 & Wylye & 140.5 & 12834 & 7.7 & 35.2 & 48.3 & 0.1 & 8.6 \\
\hline 22 & Wylye22 & Wylye & 38.8 & 8716 & 11.5 & 50.2 & 32.6 & 0.3 & 5.4 \\
\hline 23 & Wylye23 & Wylye & 156.0 & 9413 & 8.7 & 42.2 & 43.0 & 0.2 & 5.9 \\
\hline 24 & Wylye24 & Wylye & 8.5 & 4713 & 19.9 & 47.9 & 19.4 & 0.6 & 12.3 \\
\hline 25 & Nadder25 & Nadder & 34.1 & 4559 & 9.6 & 25.3 & 50.0 & 0.6 & 14.5 \\
\hline 26 & Nadder26 & Nadder & 36.4 & 5646 & 7.3 & 20.3 & 51.8 & 0.8 & 19.8 \\
\hline 27 & Nadder27 & Nadder & 101.0 & 11270 & 9.3 & 46.1 & 27.3 & 0.5 & 16.9 \\
\hline 28 & Nadder28 & Nadder & 44.0 & 13575 & 10.6 & 47.1 & 20.3 & 0.2 & 21.8 \\
\hline 29 & Nadder29 & Nadder & 14.1 & 7226 & 23.6 & 42.3 & 22.3 & 0.7 & 11.1 \\
\hline 30 & Avon30 & Main Avon & 6.9 & 9988 & 53.4 & 21.4 & 18.4 & 1.5 & 5.4 \\
\hline 31 & Avon31 & Main Avon & 0.0 & 3357 & 68.9 & 4.2 & 9.7 & 2.8 & 14.5 \\
\hline 32 & Ebble32 & Ebble & 41.1 & 7789 & 8.7 & 54.5 & 31.6 & 0.1 & 5.1 \\
\hline 33 & EBble33 & Ebble & 39.9 & 8133 & 9.4 & 58.4 & 27.0 & 0.2 & 5.1 \\
\hline 34 & Ebble34 & Ebble & 26.8 & 8725 & 14.4 & 42.9 & 37.2 & 0.3 & 5.2 \\
\hline 35 & Ebble35 & Ebble & 0.3 & 1686 & 8.9 & 17.2 & 49.4 & 2.6 & 21.8 \\
\hline 36 & Avon36 & Main Avon & 16.1 & 9846 & 23.9 & 25.5 & 34.7 & 1.1 & 14.8 \\
\hline 37 & Avon37 & Main Avon & 37.7 & 19864 & 14.2 & 35.5 & 34.4 & 1.0 & 14.9 \\
\hline 38 & Avon38 & Main Avon & 42.8 & 12472 & 12.3 & 24.1 & 40.4 & 1.1 & 22.1 \\
\hline 39 & Avon39 & Main Avon & 111.0 & 5140 & 10.7 & 37.1 & 34.2 & 0.5 & 17.6 \\
\hline 40 & Avon40 & Main Avon & 41.0 & 7975 & 7.3 & 6.2 & 43.6 & 1.7 & 41.1 \\
\hline 41 & Avon41 & Main Avon & 52.8 & 14573 & 11.1 & 4.1 & 35.4 & 2.4 & 46.9 \\
\hline 42 & Avon42 & Main Avon & 20.9 & 8301 & 10.5 & 15.2 & 41.9 & 1.4 & 31.0 \\
\hline 43 & Avon43 & Main Avon & 26.8 & 15156 & 12.5 & 10.0 & 42.1 & 1.2 & 34.3 \\
\hline
\end{tabular}

Table 2 STWs effluent average flow, nitrate $\left(\mathrm{NO}_{3}-\mathrm{N}\right)$ and ammonium $\left(\mathrm{NH}_{4}-\mathrm{N}\right)$ data between 2000 and 2009 (calibration period) and between 2010 and 2014 (validation period).

\begin{tabular}{|c|c|c|c|c|c|c|c|}
\hline & & & & \multicolumn{2}{|c|}{ 2000-2009 } & \multicolumn{2}{|c|}{ 2010-2014 } \\
\hline $\begin{array}{l}\text { STWs } \\
\text { location }\end{array}$ & River & $\begin{array}{l}\text { INCA } \\
\text { Reach }\end{array}$ & $\begin{array}{l}\text { Flow } \\
\left(\mathbf{m}^{3} / \mathbf{s}\right)\end{array}$ & $\begin{array}{l}\mathrm{NO}_{3}-\mathrm{N} \\
\text { (mg/L) }\end{array}$ & $\begin{array}{l}\text { NH4-N } \\
\text { (mg/L) }\end{array}$ & $\begin{array}{l}\mathrm{NO}_{3}-\mathrm{N} \\
\text { (mg/L) }\end{array}$ & $\begin{array}{l}\text { NH4-N } \\
\text { (mg/L) }\end{array}$ \\
\hline Amesbury & Avon & Avon17 & 0.015 & 22.60 & 3.79 & 22.60 & 2.86 \\
\hline Downton & Avon & Avon37 & 0.026 & 12.91 & 1.21 & 12.91 & 1.39 \\
\hline Fordingbridge & Avon & Avon39 & 0.028 & 19.35 & 1.38 & 19.35 & 1.00 \\
\hline Netheravon & Avon & Avon15 & 0.006 & 25.36 & 1.30 & 25.36 & 2.90 \\
\hline Pewsey & Avon & Avon08 & 0.022 & 20.58 & 3.43 & 20.58 & 2.97 \\
\hline Ratfyn & Avon & Avon16 & 0.027 & 16.92 & 2.52 & 16.92 & 1.01 \\
\hline Ringwood & Bickerley Stream & Avon41 & 0.055 & 12.52 & 1.96 & 12.52 & 2.94 \\
\hline Salisbury & Avon & Avon31 & 0.252 & 16.24 & 1.90 & 16.24 & 2.27 \\
\hline Tisbury & Nadder & Nadder26 & 0.013 & 11.47 & 0.90 & 11.47 & 0.99 \\
\hline Upavon & Avon & Avon14 & 0.006 & 16.57 & 1.59 & 16.57 & 1.20 \\
\hline Warminster & Wylye & Wylye20 & 0.018 & 20.91 & 1.49 & 20.91 & 1.11 \\
\hline
\end{tabular}




\begin{tabular}{|c|c|c|c|c|c|c|c|}
\hline Fovant & Fovant Brook & Nadder27 & 0.005 & 15.41 & 2.22 & 15.41 & 1.09 \\
\hline $\begin{array}{l}\text { Great } \\
\text { Wishford }\end{array}$ & Wylye & Wylye23 & 0.005 & 16.39 & 1.00 & 16.39 & 1.05 \\
\hline Hurdcott & Bourne & Bourne05 & 0.037 & 12.00 & 0.67 & 15.00 & 1.00 \\
\hline Barford & Nadder & Nadder28 & 0.001 & 23.61 & 1.58 & 23.61 & 3.45 \\
\hline Marden & Avon & Avon12 & 0.003 & 24.11 & 1.18 & 24.11 & 1.18 \\
\hline
\end{tabular}

Table 3 Key data required for INCA-N model parameterization and calibration.

\begin{tabular}{|l|l|}
\hline Data & Source \\
\hline Sub-catchment area & DTM (Wallingford Hydrosolutions) \\
\hline Baseflow index & CEH Hydrometric Register (Marsh and Hannaford, 2008) \\
\hline Rainfall and air temperature & Met Office \\
\hline HER and SMD & Met Office (MORCES) \\
\hline Land use data & \\
\hline Land use area in sub-catchment & $\begin{array}{l}\text { LCM2000 land coverage map (Centre for Ecology and } \\
\text { Hydrology) }\end{array}$ \\
\hline $\begin{array}{l}\text { Fertilizer and manure } \\
\text { application rates }\end{array}$ & $\begin{array}{l}\text { DEFRA farm statistics (Edina data base- University of } \\
\text { Edinburgh }\end{array}$ \\
\hline Observed data & \\
\hline Daily streamflow & Environment Agency \\
\hline Nitrate concentrations & Environment Agency (routine sampling 1-2 times a month) \\
\hline Ammonium concentrations & Environment Agency (routine sampling 1-2 times a month) \\
\hline $\begin{array}{l}\text { High frequency nitrate } \\
\text { concentrations }\end{array}$ & $\begin{array}{l}\text { University of Southampton/NOC MNC Experiment in } \\
\text { Christchurch Harbour Estuary System }\end{array}$ \\
\hline
\end{tabular}

\section{PROCESS EXPERIMENTS AND NITRATE REMOVAL RATES}

In August 2013 a set of field experiments to measure rates of nitrate removal (as $\mathrm{N}_{2}$ production) within the riverbed were undertaken in headwater tributaries of the Hampshire Avon in six $300 \mathrm{~m}$ reaches (Figure 3) of contrasting chalk, greensand and clay geology. At each reach the geomorphological characteristics of the riverbed were mapped following the method described in Gurnell and Sweet (1998). From these maps the areal cover of in-channel un-vegetated and vegetated sediment patches (including submerged, in-stream and emergent, marginal plants) was calculated and expressed as percentage cover in the reach. Rates of $\mathrm{N}_{2}$ production (here simplified to denitrification) on the riverbed surface were estimated by application of ${ }^{15} \mathrm{~N}$-labelled nitrate as described in Trimmer et al (2006) for clays and Lansdown et al (2014) for the permeable chalks and sands (Trimmer et al. unpublished). Our clay reaches did not contain any vegetated sediment patches and thus there is no data for $\mathrm{N}_{2}$ production in vegetated clay sediments. Reach-scale rates of nitrate removal $\left(\right.$ day $\left.^{-1}\right)$ calculated using measurements of denitrification in bed sediments are shown in Table 4 for the different geologies, also with and without vegetation. The different geologies and hence sediments give very different in-stream nitrate loss rates, with low values in the chalk, intermediate values for the Greensand and higher values in the clay. When all the measurements of nitrate removal in the permeable riverbed setting were grouped 
together, sediments underlying vegetation were associated with significantly higher rates of nitrate removal than un-vegetated sediments (Table 4), with an average increase for the chalk and Greensand sites of $245 \%$.

A major issue with modelling is how to calibrate models and the nitrate removal rates are crucial parameters as emphasized by Whitehead et al. (2011) and Wade et al. (2002). The advantage of having a set of process experiments is that it is possible to use the measured nitrate loss rates for the measured tributaries to extrapolate to un-monitored river reaches, or to create a weighted average to use in the modelling. Table 5 shows the averaged rates for each tributary and then the rates for the different sections of the main river system based on the underlying geology or nature of the sediments. In addition a length weighted average calculation is given for the whole river system. Note that whilst there are some significant differences between the vegetated and non-vegetated rates in the upper tributaries of the river system, the length weighted averages show little difference between the two rates (Table 5).

Table 4 Nitrate removal rates (via $\mathrm{N}_{2}$ production) for the 6 experimental sites of differing sediment geology, assuming no vegetation present due to die-back (November-April), and assuming $30 \%$ vegetation cover for Chalk streams and $15 \%$ vegetation cover for Greensand (May-October only).

\begin{tabular}{|l|l|l|c|c|c|c|}
\hline $\begin{array}{c}\text { Site } \\
\text { code }\end{array}$ & River & Geology & $\begin{array}{c}\text { No Vegetation } \\
\text { Nitrate removal } \\
\text { rates }\end{array}$ & $\begin{array}{c}\text { With Vegetation } \\
\text { Nitrate removal } \\
\text { rates }\end{array}$ & $\begin{array}{c}\text { Stream } \\
\text { depth }\end{array}$ & $\begin{array}{c}\text { Stream mean } \\
\text { NO }_{3} \text {-N } \\
\text { concentration }\end{array}$ \\
\hline & & & day $^{-1}$ & day $^{-1}$ & $\mathrm{~m}$ & $\mathrm{mg} / \mathrm{l}$ \\
\hline CE1 & Ebble & Chalk & 0.0018 & 0.0081 & 0.1 & 6.85 \\
\hline GN1 & Nadder & Greensand & 0.0280 & 0.0342 & 0.1 & 4.10 \\
\hline CW2 & Wylye & Chalk & 0.0005 & 0.0029 & 0.1 & 4.71 \\
\hline GA2 & Avon & Greensand & 0.0022 & 0.0054 & 0.1 & 4.99 \\
\hline AS2 & Sem & Clay & 0.7447 & 0.7447 & 0.1 & 1.86 \\
\hline AS1 & Sem & Clay & 0.8334 & 0.8334 & 0.1 & 1.86 \\
\hline
\end{tabular}

Table 5 Weighted nitrate removal rates estimates based on geology and reach lengths for each tributary and main Avon Rivers in INCA-N model.

\begin{tabular}{|l|l|c|c|c|}
\hline \multicolumn{1}{|c|}{ River } & Geology & Length & $\begin{array}{c}\text { No Vegetation } \\
\text { Nitrate removal rates }\end{array}$ & $\begin{array}{c}\text { With Vegetation } \\
\text { Nitrate removal rates }\end{array}$ \\
\hline & & $\mathrm{m}$ & day $^{-1}$ & day $^{-1}$ \\
\hline West Avon & Greensand & 24408 & 0.0022 & 0.0054 \\
\hline East Avon & Greensand & 37276 & 0.0022 & 0.0054 \\
\hline Bourne & Chalk & 129402 & 0.0011 & 0.0055 \\
\hline Wylye & Chalk & 101657 & 0.0005 & 0.0029 \\
\hline Nadder & Greensand & 42276 & 0.028 & 0.0342 \\
\hline Ebble & Chalk & 26334 & 0.0018 & 0.0081 \\
\hline Upper Avon & Chalk & 59824 & 0.0011 & 0.0055 \\
\hline $\begin{array}{l}\text { Middle Avon to } \\
\text { Avon 38 }\end{array}$ & Chalk & 42182 & 0.0011 & 0.0055 \\
\hline
\end{tabular}




\begin{tabular}{|l|l|l|l|l|}
$\begin{array}{l}\text { Lower Avon to } \\
\text { Avon 43 }\end{array}$ & $\begin{array}{l}\text { Sand, silt } \\
\text { clay }\end{array}$ & 51145 & 0.2684 & 0.27145 \\
\hline $\begin{array}{l}\text { Length weighted } \\
\text { Average }\end{array}$ & & & $\mathbf{0 . 0 2 9 9}$ & $\mathbf{0 . 0 3 3 9}$ \\
\hline
\end{tabular}

\section{INCA-N MODEL CALIBRATION AND VALIDATION RESULTS}

The INCA model has been calibrated for the period 2000-2009 and then validated using the period 2010-2014. For the calibration period, the simulated and observed flow for the Avon shows good agreement in the lower reaches of the river, as shown in Figure 5 . The $\mathrm{R}^{2}$ from six flow gauging stations ranges 0.67 to 0.79 and Nash-Sutcliffe efficiency ranges from 0.37 to 0.76 (Table 6). The simulation creates seasonal variations and hydrograph peaks are aligned and of similar magnitude. The flow on the recession limb in some years is however being underestimated which might reflect more sustained groundwater contribution in reality during the baseflow condition. This may indicate more groundwater recharge with a higher water table and greater amount of groundwater contribution into streams.

Flow stations in the upper reaches of the tributaries were not modelled as there is a consistent loss of water from the surface streams to the groundwater (Allen et al., 2014). This water is mostly recovered lower in the catchment as shown in Figure 4. However, the simulated flow does show a consistent bias with lower simulated flows compared to the observed. Overall this difference of $1.4 \%$ suggests that an average of $0.087 \mathrm{~m}^{3} / \mathrm{s}$ is lost to the groundwater (or deep aquifer). However, the $1.4 \%$ loss is also well within the errors associated with measuring flows in rivers which are generally in the order of $5 \%$, even for a well maintained flow gauge. So the difference could just be a bias on the flow gauge. In the validation exercise the flows are closer with no consistent bias, as shown in Figure 6.

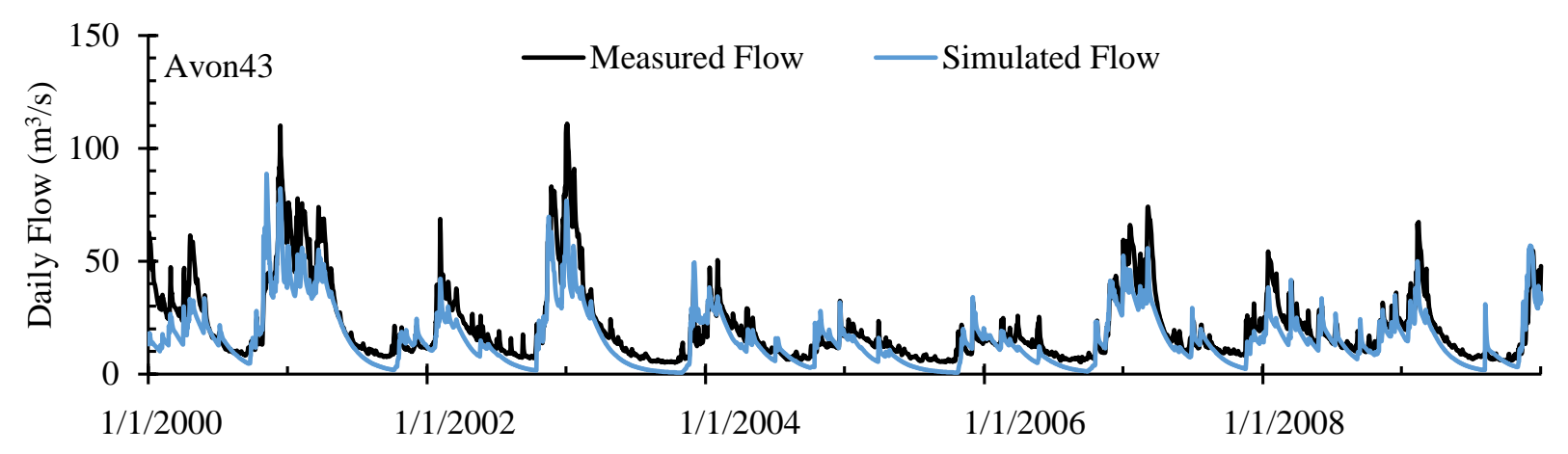

Figure 5 Simulated and measured daily flow at Knapp Mill in the lower Hampshire Avon, 2000-2009. 


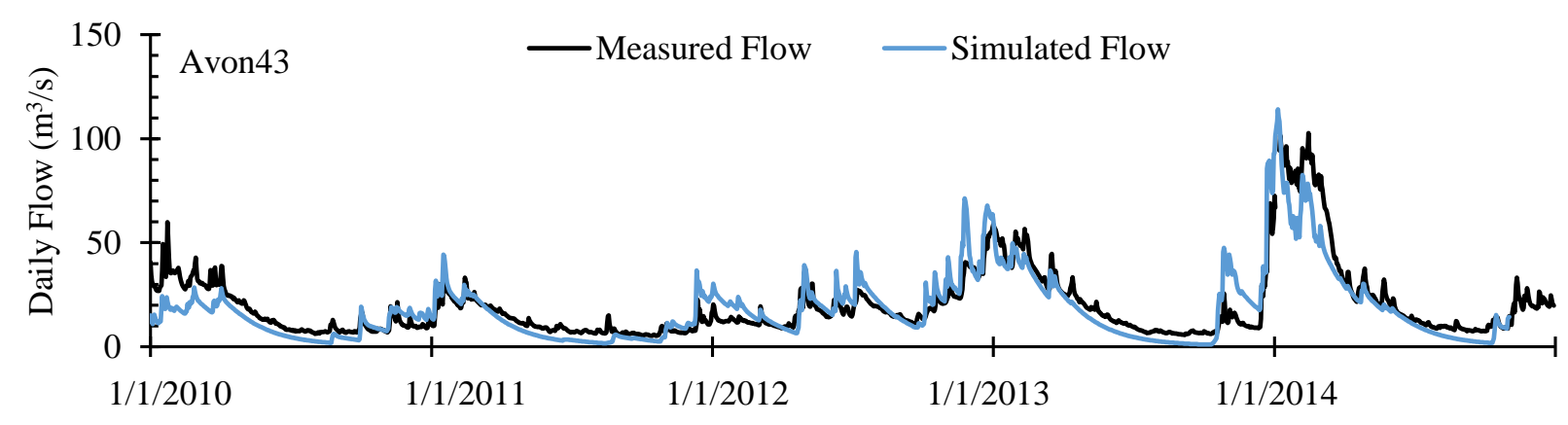

Figure 6 Simulated and measured flow at Knapp Mill in the lower Hampshire Avon, 2010-2014.

Table 6 Statistical results between daily measured flow and INCA simulated flow for calibration period 2000-2009 in the Hampshire Avon catchment.

\begin{tabular}{|l|c|l|}
\hline Reach & $\mathrm{R}^{2}$ & $\mathrm{~N}-\mathrm{S}$ \\
\hline Avon16 & 0.79 & 0.47 \\
\hline Avon38 & 0.77 & 0.61 \\
\hline Avon43 & 0.77 & 0.67 \\
\hline Ebble34 & 0.67 & 0.63 \\
\hline Wylye21 & 0.74 & 0.37 \\
\hline Nadder28 & 0.79 & 0.76 \\
\hline
\end{tabular}

For water quality, over the 10 years record (2000-2009), the simulated daily $\mathrm{NO}_{3}-\mathrm{N}$ and $\mathrm{NH}_{4}-\mathrm{N}$ for the Avon (e.g. site 38 at Ringwood) capture the main dynamics of lower concentrations in the summer and higher concentrations in the winter and spring. In this simulation the nitrate removal rates have been set to the average of the length weighted rates of 0.03 (Table 5). High flow in the winter flushes nitrate and ammonium from the soils into the streams, whilst denitrification in the summer along with lower flows reduce nitrate in the streams. In general, model accuracy was greatest in the main Avon ( $R^{2} 0.49$ to 0.78 ) and lower in tributaries $\left(\mathrm{R}^{2} 0.28\right.$ to 0.80 ). The load estimates are a key aspect of the modelling study as the DIN loads are important from an estuary management and coastal ecology perspective. In general, the model simulated loads closely matched the observed loads as shown in Figure 8, with an $\mathrm{R}^{2}$ of 0.76. However, there is some indication that the simulated loads are underestimated and this could be due to the underestimation of the flow simulation, due to the complex geology and water pathways upstream. However, the effects are more significant at the higher loads and could be related to the fact that flow gauges are less reliable at higher flows and hence could produce a bias in the observed loads. On average the fluxes are of the order of 500 tonnes per month which suggest a high load of DIN entering the estuary and coastal system. One other aspect that needs to be considered in any modelling study is that of model uncertainty. INCA-N has been the subject of many uncertainty investigations, including Whitehead et al., 1998b, Wade et al., 2002, and McIntyre et al., 2005. All these studies demonstrate that process based models are difficult to calibrate and there is always some degree of equifinality occurring, whereby processes can duplicate behaviours making it difficult to find truly unique parameter sets. In chalk systems, this is a particular problem because of the differing flow routes of water through the chalk matrix and also different processes such as DIN loss by denitrification or vegetation uptake, which 
are almost impossible to separate within a modeling study. Thus model outputs and load estimates have to be treated with caution. Nevertheless, dynamic process based models are still probably the best tool to use to combine all the complex interactions occurring.

\section{UPSTREAM-DOWNSTREAM EFFECTS}

The INCA modelling study has utilized the denitrification rates from a set of upstream measurements to determine a length weighted average for the Hampshire Avon, and this rate has proved to be the key to modelling downstream nitrogen in the river system. The INCA-N modelling has used the flow weighted denitrification rate of 0.03 for the entire catchment, as described in the results above. Figure 9 shows the nitrate simulation at Knapp Mill, the lowest river gauging point on the Avon, and just above the tidal limit of the Christchurch Harbour estuary, and compares the model results with high frequency (8-15 hour measurements) of $\mathrm{NO}_{3}-\mathrm{N}$ concentration between November 2013 and December 2014, as shown in Figure 8 with an $\mathrm{R}^{2}$ of 0.60 , which also spans a very large winter. This is an excellent fit providing confidence that the model can generate realistic time series for the downstream estuary analysis.

However, from the process experiments, a range of nitrate removal rates were obtained for the different tributaries with quite a large range of activity due to the underlying sediments and catchment geology (Table 4 and 5). In addition there is a significant difference in the rates between the vegetated and unvegetated sediments. When comparing the INCA results with the initial setup conditions, the upper reaches of the River Ebble show changes with simulated nitrate concentrations being lower with vegetation by 3\% (calculated on an annual basis), compared to the simulation without vegetation. The most significant difference, however, is found during the summer when nitrate decreases by up to $15 \%$ with inclusion of the higher nitrate removal rates assuming the presence of vegetation. The West Avon, Bourne, Nadder and Wylye tributaries show similar results, which are also attributable to the higher rates of $\mathrm{N}_{2}$ production (hence nitrate removal) measured in vegetated sediments during the summer. Under summer conditions the discharge and velocities are low and hence residence times high. Our modelling takes into account both the effect of enhanced rates of denitrification beneath macrophyte stands and of increased residence time during summer months, however there are other possible influences of vegetation on in-stream DIN removal that warrant further investigation. For example, both emergent and submerged vegetation tend to reduce water velocities, and so further increase residence time of water within sediment patches (Cotton et al., 2006). Also ammonium and nitrate will be directly taken up by in-stream vegetation as nutrients for plant growth (Clarke et al., 2002). In INCA plant uptake in the stream is not explicitly modelled so this separate effect cannot be simulated. However, in the upper reaches these preliminary modelling results suggest that aquatic vegetation could be having an effect on $\mathrm{N}$ removal rates, enhancing the reduction of nitrate loads due to denitrification in the river system. 

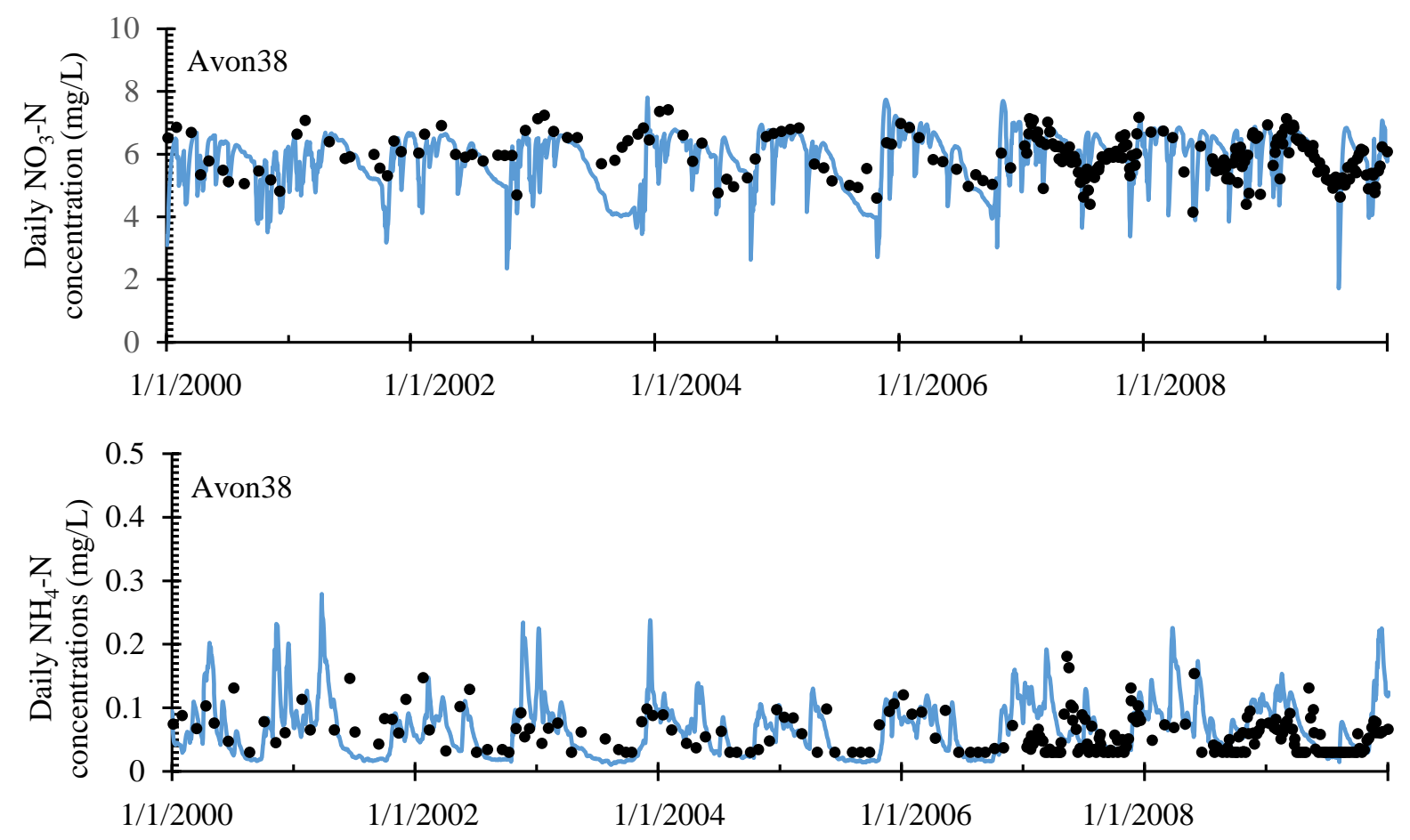

Figure 7 Simulated (line) and measured (dots) $\mathrm{NO}_{3}-\mathrm{N}$ and $\mathrm{NH}_{4}-\mathrm{N}$ concentrations at Ringwood, 20002009.

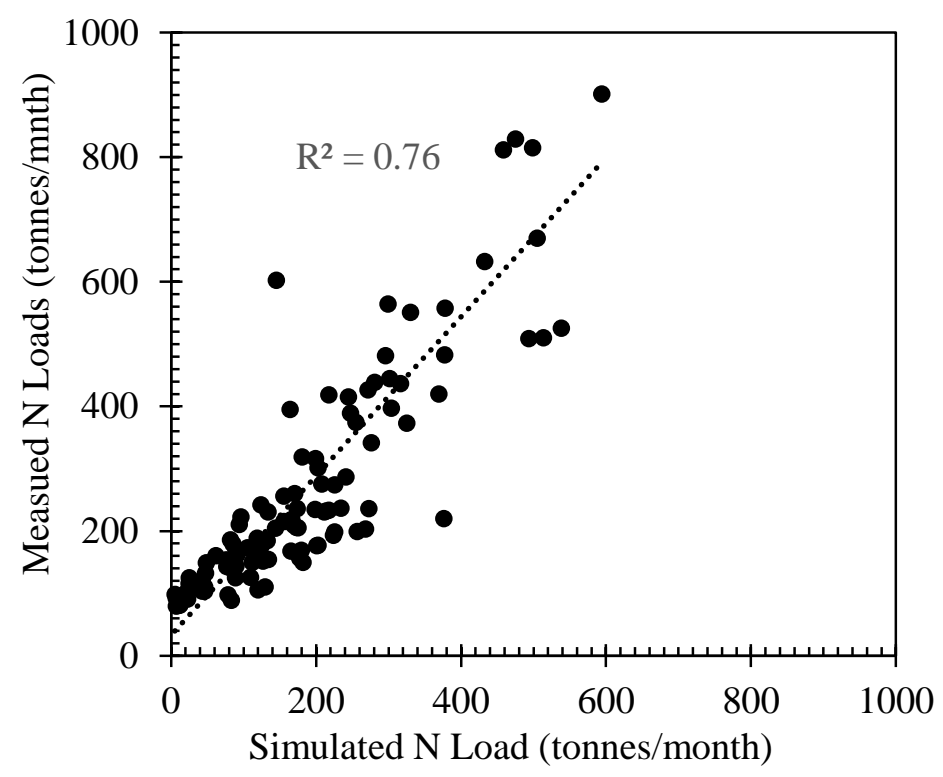

Figure 8 Monthly simulated and observed N loads in the lower Hampshire Avon at Ringwood from 2000 to 2009 (Reach Avon38). 


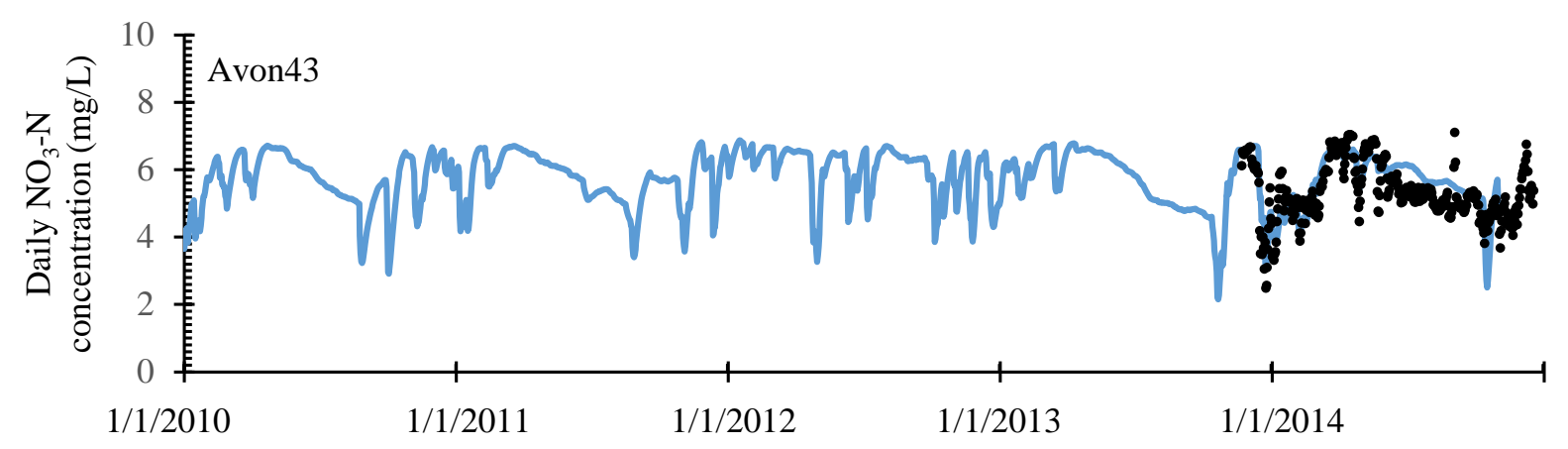

Figure 9 Simulated Nitrate-N (line) and daily high frequency (8-15 hour) measured Nitrate-N (dots) at Knapp Mill.

\section{MITIGATION - AN ENHANCED NVZ STRATEGY FOR THE HAMPSHIRE AVON}

Nitrate Vulnerable Zones (NVZs) are a regulatory tool that places requirements on farmers to take additional measures to protect air, soil and water from nitrates. Such measures include

1. Plans for the use of $\mathrm{N}$ fertilizer and livestock manure;

2. Risk maps for areas to which manure is to be spread;

3. Compliance with field limits, crop $\mathrm{N}$ requirement limits, closed periods and spreading controls for manufactured $\mathrm{N}$ fertilizers and organic manures;

4. Compliance with livestock manure $\mathrm{N}$ farm limit;

5. Adequate storage capacity for livestock manure;

6. Records of the $\mathrm{N}$ applied to fields and whole farms.

The NVZ strategy is applied in the UK with certain land areas selected within catchments depending on land use and vulnerability, in order to protect underlying aquifers. It has been difficult to see a major impact of this strategy in the UK (Burt et al., 2011; Howden et al., 2010), although there are signs that reductions are beginning to have an impacts (Howden et al., 2010). However, in Denmark, since 1985, seven National Action Plans have been implemented to reduce the $\mathrm{N}$ discharge from point sources and $\mathrm{N}$ losses from agriculture (Kronvang et al., 2008). The plans have included regulations on point source discharges from waste water treatment plants, area-related measures (e.g. re-establishment of wetlands, afforestation and use of catch crops) and nutrient-related measures (e.g. mandatory fertilizer plans and improved utilization of $\mathrm{N}$ in manure). Since 1985, the loading of $\mathrm{N}$ from point sources has been reduced by 74\% (1989-2003), the field $\mathrm{N}$ surplus by 31\% (1990-2003). There have been significant long term reductions in nitrates as a results with reduced leaching from the root zone on agricultural land by 33\% (1989-2002), and the total nitrogen (TN) concentrations in 86 streams draining agricultural catchments by 32\% between 1989 and 2004 (Kronvang et al., 2008).

In order to assess what might happen in the Hampshire Avon a NVZ strategy has been simulated in the model assuming a start of NVZ in 2000, assuming a similar scenario as in Denmark, with a $75 \%$ reduction in point sources, and a 30\% reduction in $\mathrm{N}$ fertilizer additions. The results of the model at three sites down the Avon with Avon43 representing the downstream Knapp Mill site are shown in Table 8. The results indicate that both nitrate and ammonium concentrations would fall, with an average reduction of $10 \%$ compared to the mean nitrates over the 2000-2009 period. This reduction over the 10 
year period if continued for 30 years would reproduce the reduction levels observed in the Danish catchments. However, it is a very long term process due to the long residence times associated with the underlying chalk aquifers.

Table 8 Nitrate, ammonium concentrations (mg N/L) over the 2000-2009 period compared to the NVZ strategy with \% change.

\begin{tabular}{|l|c|c|c|c|c|c|}
\hline & \multicolumn{2}{|c|}{$2000-2009$} & \multicolumn{2}{c|}{ NVZ Scenario } & \multicolumn{2}{c|}{ \% Change } \\
\hline Site & Nitrate & Ammonium & Nitrate & Ammonium & Nitrate & Ammonium \\
\hline Avon15 & 6.09 & 0.08 & 5.4 & 0.069 & 11.3 & 13.8 \\
\hline Avon38 & 5.77 & 0.072 & 5.21 & 0.058 & 9.7 & 19.4 \\
\hline Avon43 & 5.71 & 0.066 & 5.17 & 0.056 & 9.5 & 15.2 \\
\hline
\end{tabular}

\section{CONCLUSIONS}

The modelling of DIN in rivers is complex because of the interactions between flow, water velocity, nitrate removal rates, underlying geology and vegetation. This study has bought all these factors together making use of the INCA-N model to link all the processes and hydrochemical dynamics. The upstream process experiments have proved to be valuable in establishing differing nitrate loss rates in the different tributaries, with and without vegetation. Thus spatially these differences need to be modelled explicitly and scaling up from site specific experiments to the whole reach and whole river system is required. This is a difficult problem but the length weighted procedure used in the Hampshire Avon has proved to be valuable, generating an overall nitrate loss rate that correctly predicts nitrate concentrations in the lower reaches of the river. The process experiments have proved to be one way to provide extra information to assist with the complex problem of parametrization of process based models. In terms of mitigation, the NVZ strategy is a route that has certainly worked in Denmark over a 30 year period. The modelling of the Hampshire Avon has suggested that the NVZ strategy should reduce the nitrate concentrations but over a long time scale.

\section{Acknowledgement}

We would like to acknowledge the funding support of two NERC grants: NE/J012106/1 'The role of lateral exchange in modulating the seaward flux of C, N, P.' awarded to Queen Mary University of London and NE/J012238/1 'Quantifying annual cycles of macronutrient fluxes and net effect of transformations in an estuary: their responses to stochastic storm-driven events' awarded to University of Southampton as a component of the NERC Macronutrients programme. We would also like to thank the five generous landowners and farmers in the catchment of the Hampshire Avon who gave us permission to work in our selected river reaches. We would also like to thank Environment Agency for proving observed flow and water quality data. Thanks to Dan Butterfield for his technical support on the multi-branched INCA-N model. Lastly thanks go to two anonymous reviewers for their comments. 


\section{References}

Allen DJ, Darling WG, Davies J, Newell AJ, Gooddy DC, Collins AL. Groundwater conceptual models: implications for evaluating diffuse pollution mitigation. Quarterly Journal of Engineering Geology and Hydrogeology 2014; 47: 65-80.

Bryan G, et al., Phosphorus in the Hampshire Avon Special Area of Conservation Technical Report. 2015.

Burt TP, Howden NJK, Worrall F, Whelan MJ, and Bieroza MZ. Nitrate in United Kingdom rivers: Policy and its outcomes since 1970. Environmental Science \& Technology 2011; 45:175-81

Carmargo JA and Alonso A. Ecological and toxicological effects of inorganic nitrogen pollution in aquatic ecosystems: A global assessment 2006; 32: 831 - 849.

Clarke S, 2002, Vegetation growth in rivers: influences upon sediment and nutrient dynamics. Progress in Physical Geography 26(2): 159-172.

Cotton JA, Wharton G, Bass JAB, Heppell CM, and Wotton RS, 2006, The effects of seasonal changes to instream vegetation cover on patterns of flow and accumulation of sediment. Geomorphology 77(3-4): 320-334.

Cox B. A review of currently available in-stream water-quality models and their applicability for simulating dissolved oxygen in lowland rivers, The Science of the Total Environment 2003; 314-316: 335-377, doi:10.1016/S0048-9697(03)00063-9.

Fowler D, Sutton MA, Smith RI, Pitcairn CER, Coyle M, Campbell G, Stedman J. Regional mass budgets of oxidized and reduced nitrogen and their relative contribution to the $\mathrm{N}$ inputs of sensitive ecosystems. Environmental Pollution 1998; 102: 337-342.

Fowler, D, O’Donoghue, M, Muller, J, Smith, RI, Dragosits, U, Skiba, U, Sutton, MA, Brimblecombe, P. The chronology of nitrogen deposition in the UK between 1900 and 2000. Water, Air and Soil Pollution: Focus 2004; 4 (6): 9-23.

Galloway JN, Winiwarter W, Leip A, Leach AM and Erisman JW. Nitrogen footprints: Past, present and future, Environmental Research Letters 2014, 9, 11, DO - 10.1088/1748-9326/9/11/115003.

Grizzetti B, Bouraoui F, Billen G, Grinsven HV, Cardoso AC, et al. Nitrogen as a threat to European water quality in The European Nitrogen Assessment Sources, Effects and Policy Perspectives. 2011, pp. 379-404

Gurnell AM and Sweet R. The distribution of large woody debris accumulations and pools in relation to woodland stream management in a small low, gradient stream. Earth Surface Processes and Landforms 1998; 23: 11011121.

Hansen B, Thorling L, Dalgaard T, Erlandsen M. Trend reversal of nitrate in Danish groundwater--a reflection of agricultural practices and nitrogen surpluses since 1950. Environ Sci Technol 2011; 45: 228-34.

Jarvie HP, Sharpley AN, Spears B, BudaAR, May L, Kleinman PJA. Water quality remediation faces unprecedented challenges from “Legacy Phosphorus”. Environmental Science and Technology 2013; 47: 89978998.

Howden NJK, Burt TP, Worrall F, Whelan MJ, Bieroza M. Nitrate concentrations and fluxes in the River Thames over 140 years (1868-2008): Are increases irreversible? Hydrological Processes 2010; 23:2657-62.

Kronvang B, Andersen HE, Børgesen C, Dalgaard T, Larsen SE, Bøgestrand J, Blicher-Mathiasen G. Effects of policy measures implemented in Denmark on nitrogen pollution of the aquatic environment. Environ. Sci. Policy 2008; 11:144-152. 
Lansdown K, Heppell CM and Trimmer M. Temporal and spatial variations in denitrification rates across contrasting geologies in a lowland agricultural catchment. 2015. In prep.

Lansdown K, Heppell CM, Dossena M, Ullah S, Heathwaite AL, Binley A, Zhang H \& Trimmer M. Fine-scale in situ measurement of riverbed nitrate production and consumption in an armored permeable riverbed. Environmental Science and Technology 2014; 48, 4425-4434.

McIntyre N, Jackson B, Wade AJ, Butterfield D and Wheater HS. Sensitivity analysis of a catchment-scale nitrogen model. Journal of Hydrology 2005; 315 1-4: 71-92. doi:10.1016/j.jhydrol.2005.04.010.

Neal C, Bowes M, Jarvie HP, Scholefield P, Leeks G, Neal M. et al., Lowland river water quality: a new UK data resource for process and environmental management analysis. Hydrologic Processes 2012; 26: 949-960.

Neal C, Jarvie HP, Neal M, Hill L, Wickham H. Nitrate concentrations in river waters of the upper Thames and its tributaries. Science of The Total Environment Volume 2006; 365: 15-32.

Purdie DA, Panton A. and Fones G. Macronutrient fluxes in the Hampshire Avon River derived from high frequency monitoring. Science of The Total Environment 2015; MNC special issue.

Sala OE, Chapin III FS, Armesto J.J, et al., Global biodiversity scenarios for the year 2100. Science 2000; 287: $1770-1774$.

Thompson N, Barrie IA, Ayles M. The Meteorological Office rainfall and evaporation calculation system (MORECS). Hydrological Memorandum 1981; 45. Met. Office 8, Bracknell, UK.

Tipping E, Thacker SA, Wilson D, Hall JR. Long-term nitrate increases in two oligotrophic lakes, due to theleaching of atmospherically-deposited N from moorlandranker soils. Environmental Pollution 2008; 152: 41-49.

Trimmer M, Risgaard-Petersen N, Nicholls JC, Engstrom P. Direct measurement of anaerobic ammonium oxidation (anammox) and denitrification in intact sediment cores. MEPS 2006; 326: 37-47.

Trimmer M, Sanders IA, Heppell CM. Carbon and nitrogen cycling in a vegetated lowland chalk river impacted by sediment. Hydrol. Proc. 2009; 23: 2225-2238.

Wade AJ, Durand P, Beaujouan V, Wessel WW, Raat KJ, Whitehead PG, Butterfield D, Rankinen K, Lepisto A. A nitrogen model for European catchments: INCA, new model structure and equations. Hydrology and Earth System Sciences 2002; 6: 559-582.

Whitehead, P.G, and Crossman, J. 2012. Macronutrient Cycles and Climate Change: Key Science Areas and an International Perspective. Sci. Total Env. 434: 13 - 17

Whitehead PG, Wilson EJ, Butterfield D. A semi-distributed nitrogen model for multiple source assessments in catchments (INCA): Part 1 - model structure and process equations. Sci. Total Env. 1998a; 210/211: 547-558.

Whitehead PG, Wilson EJ, Butterfield D, Seed K. A semi-distributed integrated flow and nitrogen model for multiple source assessment in catchments (INCA): Part 2 Application to large river basins in South Wales and Eastern England. Sci. Total Env. 1998b; 210/211: 559-583.

Whitehead PG, Jin L, Baulch HM, Butterfield DA, Oni SK, Dillon PJ, Futter M, Wade AJ, North R, O’Connor EM, Jarvie H. Modelling phosphorus dynamics in multi-branch river systems: a study of the Black River, Lake Simcoe, Canada. Science of the Total environment 2011; 412-413: 315-23.

Whitehead PG, Jin L, Crossman J, Comber S, Johnes PJ, Daldorph P, Flynn N, Collins AL, Butterfield D, Mistry R, Bardon R, Pope L, Willows R. Distributed and dynamic modelling of hydrology, phosphorus and ecology 
in the Hampshire Avon and Blashford Lakes: Evaluating alternative strategies to meet WFD standards. Science of the Total Environment 2014, 481: 157-166. 